\title{
Exploring Christian therapists' experience of the Impact of the COVID-19 Pandemic on their faith and spirituality: An interpretative phenomenological analysis
}

\author{
Sookyung Yang
}

\begin{abstract}
Aim: The present study carried out a qualitative exploration of the impact of COVID-19 on Christian therapists' faith and spirituality.

Method: Semi-structured interviews were conducted with five female Christian therapists, which served as the crux of the study, using the interpretative phenomenological analysis framework (IPA).

Findings: IPA analysis of the interviews revealed three superordinate themes and ten subordinate themes. The three superordinate themes that emerged were as follows: dealing with the sudden sense of loss brought on by the COVID-19 pandemic; adaptation and spiritual growth; religion and spirituality as a coping mechanism in response to the global crises. The findings are discussed in the light of previous research and psychological theory. The quality and limitations of this study are also considered, alongside proposals for potential research prospects going forward. Taken together, it can be observed that the pandemic led to a multifaceted reaction that tested the depth of the participants' Christian faith and spirituality. Eventually, however, it remained steadfast with the participants showcasing a renewed relationship - both with God, and indeed with themselves.
\end{abstract}

\section{Introduction}

\section{Background and rationale}

The COVID-19 pandemic has presented unprecedented health challenges throughout the world (Pfefferbaum \& North, 2020; Rogers et al., 2020). Previous research has shown that infectious disease outbreaks have been followed by drastic individual and psycho-socioeconomic impacts, which have been exacerbated to become more pervasive than the epidemic itself ( $L i$ et al., 2020; Ornell et al., 2020). Although empirical research on the impact of COVID-19 on religious faith and spirituality have been limited to date, a significant body of research has since demonstrated robust links between trauma (such as epidemics and natural disaster) and spiritual and religious struggles (Pargament et al., 2014; Richards and Bergin, 2014).

The closure of church buildings and religious institutions during the pandemic resulted in the inability to actively engage in congregational life. This can bring about negative influences on mental health and wellbeing (psychological and spiritual), especially for those who belong to religious traditions in which regular and active participation in their religious group is a strong norm (Douthat, 2014; Lim, 2015).

Moreover, given the potential for major life crises to shake people deeply both psychologically and spiritually, the pandemic has intensified the need for therapists to address clients' religious and 
spiritual issues and to consider spiritual wellbeing as a critical component of holistic care for clients in this most challenging time (Ellison and Lee, 2010; Krause, 2015; Bell et al., 2020:1). As such, detailed insights from qualitative studies on the impact of the pandemic on Christian therapists' faith and spirituality are necessary to facilitate the development of refined intervention techniques for the benefit of clients' and therapists' psychological and spiritual wellbeing (Holmes et al., 2020:547; Roman et al., 2020:1).

This research focuses on exploring Christian therapists' experience of the impact of the COVID-19 pandemic on their faith and spirituality.

\section{Literature review}

\section{The Impact of COVID-19 on mental health}

The COVID-19 pandemic has brought with it profound consequences, not only for one's physical health, but also for the mental wellbeing of the population (Pfefferbaum \& North, 2020:510; Lucchetti et al., 2020:1). One of the most widely practised methods of public health control continues to be social distancing (Lucchetti et al., 2020: 2). Consequently, the prescribed sense of isolation that comes with adhering to these measures have contributed extensively to the widespread increase in depression, stress and anxiety related issues, which have flared up in vulnerable individuals especially (Lopes \& Jaspal, 2000; Shader, 2020; Kanter \& Manbeck, 2020). Such psychological consequences can have implications that are both short and long term, and are likely to increase the prevalence of anxiety, depression, insomnia and post-traumatic stress (Rogers et al., 2020; 616-622) and other variables related to maintaining one's wellbeing (Umucu et al., 2020; Fisher et al., 2020; Arslan et al., 2020).

With regards to the various channels through which the pandemic has impacted psychological wellbeing, recent studies (i.e.,Hamouche, 2020:4-5) have suggested that COVID-19-related psychological distress may be caused by multiple stressors (a combination of determinants) such as environmental (e.g., social disconnection, stigma; Xiang et al., 2020), organisational (e.g., job insecurity; Zhou et al., 2020; Brooks et al., 2020), as well as other supplementary factors (e.g., the risk of contagion, financial loss; Zhang et al., 2020; Wang et al., 2020). And the psychological burden that the ongoing pandemic has placed on individuals can be especially high for vulnerable demographics, including individuals with pre-existing mental health issues, patients with the virus and their families, the elderly, and healthcare workers (Rajkumar, 2020; Dubey et al., 2020).

It is therefore crucial that mental health is taken into consideration at multiple levels, including age, occupation (employment), status, and socioeconomic and religious factors (Lopes \& Jaspal, 2020:466; Holmes et al., 2020:547). An essential strategy that may prove useful in reducing pandemic-related stress, and lead to improvements in one's mental health, is that of spiritual care. It is commonly known that such forms of treatment are directly linked to a broader range of indicators, such as finding a greater sense of purpose and meaning in life and increased satisfaction with themselves - all of which are key pillars of supporting an individual's mental wellbeing (Unterrainer et al., 2014; Shirkavand et al., 2018). Furthermore, evidence shows that religiosity and spirituality (R/S) are more seriously considered during life crises and that utilising clients' religious beliefs and practices are associated with better clinical outcomes (Hook et al., 2010; Hodge, 2006; Lim et al., 2014). 


\section{Christian religiosity in the midst of the pandemic}

As the UK government imposed a series of lockdowns and implemented social distancing measures, these COVID-19-related restrictions have impeded the progress of religious practices significantly (Roman et al., 2020; Campbell, 2020). It is important to note that religious practices, by their nature, are concentrated around religious communities. Social distancing therefore interrupts the opportunity to engage in faith-based activities that may have implications for multiple domains of wellbeing (Sulkowski \& Ignatowski, 2020: 11-12; Coppola, 2021:1).

In response to these restrictions, churches have introduced various offline and online initiatives to minimise the disruption caused by the pandemic (Meza, 2020: Campbell, 2020). Although the transfer of the Church to the online platform was deemed as being a 'pragmatic response' (Campbell, 2020:10), certain academic sources soon began to illustrate the setbacks of engaging in religious practices through a virtual medium (Bare, 2020:36; Garner, 2020:56). According to Nye and Lobley (2020:14), while many have turned to the internet for worship and community connection, others have found it to be simply inaccessible (predominantly at a personal level), stating that it intensifies their sense of separation. Indeed, the elderly and those with limited digital access particularly tended to find it difficult to engage with, either technologically or emotionally due to the mentioned constraints.

Nonetheless, there is some evidence to vouch for the increased manifestation of religious activity during the pandemic (Bentzen, 2020; Coppen, 2020). In fact, during the first few months following the initial outbreak of the virus, there were several reports that indicated the revival of religious practices in many parts of the world (Bentzen, 2020; Gareli, 2020; Gecewicz, 2020). Possible explanations for this soaring interest could be that when faced with dramatic and life-threatening situations such as illness, war, unemployment or extreme poverty, people have the tendency to seek solace in religious coping mechanisms, thus reducing their psychological stress levels (Pargament, 1997; Lopes and Jaspal, 2020).

\section{Religious and spiritual (R/S) struggles and coping}

Given that religious faith and spirituality contributes to the formation of one's ethics, values and their interpretation of the meaning of life (Pargament et al., 2014; Richards and Bergin, 2014), it is important to recognise that the pandemic may trigger profound religious and existential questions as people struggle with issues of uncertainty, loss, and tragedy (Lee, 2020; Nye and Lobley, 2020). Religious and spiritual (R/S) struggles are termed as being 'conflicts, strains, and tensions on religious and/or spiritual issues' (Exline and Rose, 2013:460). Individuals whose religious beliefs, values and practices are central to their guiding orientation in life or to their primary worldview tended to find that their religious and spiritual struggles often shook them to the core, resulting in psychological distress and a decline in their mental and physical wellbeing (Pargament, 1997; Noth \& Lampe, 2020).

Although empirical research on COVID-19 and the R/S struggle is yet to gain traction ${ }_{L}$ existing studies have shown that there is a clear relationship between trauma, illness and religious/spiritual struggles (Exline, 2013; Park et al., 2011; Lee, 2020). In the context of the pandemic, individuals who struggled with suffering, loss, and uncertainty, further experienced 'conflict, question and doubt regarding matters of faith, God and religious relationships' 
(McConnell et al., 2006;1470). For example, due to the suffering caused by the pandemic, some individuals may have experienced negative feelings toward God; exacerbated further by the feeling of being unprotected, or the inability to place their trust in God in the midst of all their fears and anxieties (Exline et al., 2014: Counted et al., 2020). Also, some religious individuals may have seen the pandemic as being a punishment for their sins or wrongdoings, resulting in feelings of anger developing towards God or doubts about the truth of their religious faith, or indeed questions about the ultimate meaning and purpose of life (Lee, 2020; Nye and Lobley, 2020).

Nonetheless, R/S struggles may instead result in inherently positive changes and spiritual growth (Stauner et al., 2016; 48; Exline et al., 2017:501). This can be corroborated by the fact that posttraumatic growth often occurs on the back of a prolonged period of suffering (Philippians.3:10; Powlison, 2018). Studies have shown conflicting evidence for spiritual growth during the pandemic (Bare, 2020; Meza, 2020; Coppola et al., 2021). The Pew Research Center survey found that while few people (for example, in Spain and America) say their religious faith has weakened as a result of the pandemic, people who prioritise religion are more likely to say COVID-19 strengthened their religious faith (Pew Research Center, 2021). It is crucial to acknowledge the fact that even though religious individuals may experience R/S struggles, those struggles might indeed act as a precursor for positive change and spiritual growth that may in turn lead to a healthier engagement with their surroundings (Pargament, 1997; Exline et al., 2017).

Although much of the literature on religion and mental health focuses on the positive influence of religion, some researchers suggest that negative religion induced coping strategies may result in an increased sense of distress by provoking R/S struggles that can harm one's mental health (Pargament \& Ano, 2006; Mantyla, 2020; Doehring, 2020). Research conducted by Yingling and Froese (2020:311) found that an individual's sense of control may vary with religiosity, and relational direction may change according to a person's perceived image of God, which is further influenced by their socioeconomic status. Specifically, they found that believing in a judgmental God was negatively associated with a sense of agency.

The literature review highlights the fact that COVID-19 and the subsequent social distancing imposed by the series of lockdowns not only threatened people's psychological health but also influenced their religious and spiritual life (Sulkowski \& Ignatowski, 2020; Lucchetti, et al., 2020).

Currently, there are a limited number of scientific studies on the impact of COVID-19 on religion and spirituality, with existing research mostly using quantitative methods. To the best of the researcher's knowledge, no studies have employed interpretative methodologies to examine the lived experiences of Christian counsellors and psychotherapists in such a way within the UK.

The research question therefore was: 'exploring Christian therapists' experience of the impact of the COVID-19 pandemic on their faith and spirituality'.

\section{Methodology}

Research Design and Epistemology

This study aims to explore how Christian therapists experience and interpret the impact of COVID19 on their faith and spirituality using interpretative phenomenological analysis (Smith, Flowers \& 
Larking, 2012). Qualitative research was considered to be the most befitting for this enquiry, given the need for a detailed breakdown of the individual's subjective experiences within their social world (Emslie, 2005; Smith, Flowers \& Larkin, 2012).

Five Christian therapists were recruited in line with the sampling criteria of the IPA (Smith et al., 2012). To protect participants' anonymity, pseudonyms were used. As the data was collected during the third UK lockdown (February-March 2021), all the corresponding interviews were conducted by video-call due to the imposed restrictions.

\section{Research Findings}

\section{Introduction}

Analysis of the interview data revealed three interconnected superordinate themes: the initial impact of COVID-19 and dealing with the sudden sense of loss; adaptation and spiritual growth; and religion and spirituality as a coping resource. Each of these superordinate themes has several related subordinate themes and these are presented in Table 1.

\begin{tabular}{|c|c|}
\hline Superordinate themes & Subordinate themes \\
\hline \multirow[t]{4}{*}{$\begin{array}{l}\text { The initial impact of COVID-19 and dealing with the } \\
\text { sudden sense of loss }\end{array}$} & A sudden loss of organisational religious activities \\
\hline & A loss of social connection \\
\hline & A loss of social support \\
\hline & Religious and spiritual challenges \\
\hline \multirow[t]{3}{*}{ Adaptation and spiritual growth } & Changes in religious practices \\
\hline & Technologically meditated religious practices \\
\hline & Spiritual growth \\
\hline \multirow[t]{3}{*}{ Religion and spirituality (R/S) as coping resources } & $\mathrm{R} / \mathrm{S}$ as a cognitive resource \\
\hline & $\mathrm{R} / \mathrm{S}$ as a psychological resource \\
\hline & $\mathrm{R} / \mathrm{S}$ as a social resource \\
\hline
\end{tabular}

Table 1: Superordinate themes and subordinate themes 


\section{The Initial Impact of COVID-19 and dealing with the sudden sense of loss}

As the participants began to talk about the closing of churches and religious institutions, there seemed to be a noticeable sense of 'sudden loss' or 'grief', which resulted in sudden changes to their spiritual engagement. Alongside this sense of 'sudden loss', participants also expressed a powerful longing for their congregational gatherings and faith communities. Specific issues that were discussed can be represented within the following three subordinate themes.

\section{The sudden loss of organisational religious activities}

A sub-theme that was directly linked with the outbreak of COVID-19 was the participants' experiences of how COVID-19 restrictions forced places of worship to stop or limit services, with many moving to online forms of worship.

Annie reflected on how the pandemic affected her normal religious practice, saying:

'I just didn't have any routine in it, and I think the pandemic forced a change of routine. I've just lost that consistency with God really. And it's been a struggle... my church went online but to be honest, I forget what has been said in the church service because I haven't been attending or, alternatively, I listen later in the week.'

When COVID-19 disrupted our lives abruptly, 'the feeling of no longer having collective worship and congregational gatherings' was described by the participants as being 'so painful'. And Olivia's narrative described how it was affecting her spiritual identity: 'I felt like I lost a part of who I am... my life used to revolve around church activities such as Bible studies and women's fellowship.'

\section{The loss of social connection}

Another subordinate theme that can be discussed, in the context of the loss of in-person collective worship, was the loss of face-to-face contact with fellow worshippers, which left participants feeling disconnected. Participants' narratives described how they experienced relational losses with respect to the Christian community. Caroline stated, within a very short period of time, so many in-person gatherings have been cancelled... I missed the powerful moments when we, as the body of Christ, came together for a common purpose, hearing each other's voices and seeing each other.'

Connecting via online platforms such as Zoom, or FaceTime has proven to enhance offline relationships (Campbell 2012:7). Yet, it seems as though virtual contact cannot, in any sense, replicate one's physical presence. Jenny shared, '...being on a screen is OK but there's not that much interaction... we do have Facetime... the family and the interactive body of the church... part of that relationship has kind of been lost a bit and so I feel a bit numb, a bit at a loss for that part (1-2:74-75).' These forms of online religious practices may in turn promote other negative outcomes such as 'Zoom fatigue' (Wiederhold, 2020: 437). In-person interactions within faith communities seemed to be an essential feature of 'feeling connected'.

The loss of social support

Participants highlighted 'the loss of social support' proffered by faith communities that they usually relied upon, being fractured by lockdowns and social distancing. Religious practices can be a 
source of social support through a variety of means - similar sentiments were echoed by all the participants.

Throughout Caroline's interview, she often explained how she incurred relational losses tied to the Christian community, which had previously offered her an accountable place in which she could both serve others and be sustained by them: I was an active member of the women's group... I helped out at this coffee shop. All of those friendships that I had made are now gone... Those friendships are probably the biggest losses... I felt like I was missing something.'

Lucy specifically expressed how being disconnected from the faith-based community affected her emotional wellbeing, which contributed to the challenges in acquiring replacement support, saying: 'Not having that social support, meeting with other people which would encourage me... that was taken away so I had to make an adjustment in terms of what I would normally do for self-care.'

\section{Religious and spiritual challenges}

Each of the participants talked about how they had experienced tremendous religious and spiritual challenges brought about by the COVID-19 pandemic.

A year into the pandemic, Jenny explored her experiences of spiritual numbness, and the desert place represented the feeling of numbness that was slowly building up inside her, saying: My faith... I mean praying to God and relying on God... is always there, but I feel quite numb in some places[respects]. So sometimes it's been quite hard, but it is always, you know... God is constant. God is there always... the whole experience is like being in a desert place.'

As the global pandemic forced people to confront the unprecedented sense of uncertainty and chaos (Bentzen 2020), it seemed as though the impact on the participants' faith were manifold, including feelings of disorientation and isolation. For Annie, it also gave her the grounds to question her unexamined beliefs. This led to new struggles as the faith, that she said she once had, was being eroded away. Annie mentioned, '... at the beginning of the pandemic, I was kind of challenging those beliefs mostly because of family influences... it really challenged what I believed in and why I believed it... I needed to be stripped of the control I thought I had and removed from my faith community in order to challenge my beliefs... it has left me feeling quite disorientated.'

\section{Adaptation and spiritual growth}

Despite the feelings of loss, grief, and the challenges of engaging in worship, participants described how COVID-19 pushed them to change the way they practise their faith. This second theme captures the participants' descriptions of their ways of adapting to such changes, which fortuitously led to spiritual growth.

\section{Changes in religious practices}

One big difference was that COVID-19 quickly affected institutional religiosity; adjustments to personal religious practices were a major part of the participants' response to the impact of the lockdown and social distancing. 
Lucy reported that her church closing increased her awareness of the need to adjust: 'I know I still need to find ways at home to do that... I mean things like Bible reading and praying that sort of thing... I've been more intentional about praying for my clients.' Both Caroline and Jenny said that they believed that their personal devotional practices were more frequent than those organised by their churches. Caroline reflected: 'I was busy before the pandemic and rushed through the scriptures. Nowadays, I am able to spend the mornings reading God's word with greater focus [and I do] (C-3:96-97).'

Interestingly, in the context of the pandemic, the 'natural world' was incorporated into conventional spiritual practices. Olivia noted the following: 'So I can put the music on, whatever, I can take the dog out for walk, say hi to people, meet other people also affected by the pandemic. COVID19 has meant that I stop to watch a sunrise or a sunset... I feel closest to God when I am on my own in nature... My spiritual practices during these times have helped me stay grounded and feel connected.'

\section{Technologically-mediated religious practices}

The participants reported that the pandemic gradually changed the ways they practise their religion. Despite disruption and the evident challenges, participants said that the restrictions have pushed them to adapt to virtual religious activities to engage in worship and stay connected with their faith and religious communities.

Lucy illustrated some examples of how she would spend time exploring things that she never really thought of doing before the pandemic. She noted, 'It [the pandemic] kind of pushed me more and more into using things like the 24/7 Prayer app, whereas previously I was convinced that was so isolating. Why would I want to use my mobile phone to connect all of a sudden with these things? Although in fact they became really useful and only recently I started to listen to Premier Christian radio and watch things on YouTube that I wouldn't normally watch.'

Online religious resources can make it easier to incorporate religious practice into a busy daily life. Annie stated, 'So he [my husband] introduced me to YouTube clips of American gospel and he also introduced me to different online courses... it's so much nicer not having to go out... we just sit on the sofa with a cup of tea (A-5:190-193).'

Yet, while some participants recognised advantages to virtual worship or religious practices, Caroline reported some practical disadvantages. As Caroline put it: 'Sitting at my desk in front of my laptop is a different experience from laying on my couch with my Bible and prayer notes... The computer drew me away from reflection and reading (C-4:121-124).'

\section{Spiritual growth}

All the participants expressed an experience of significant spiritual growth through the challenging circumstances brought on by COVID-19. For most, they reported that their spiritual growth came from re-evaluating their beliefs, religious life, or priorities, gaining new insights about themselves and/or the world.

Lucy talked about how COVID-19 brought about spiritual growth: 'And I guess it's [the COVID-19 pandemic] that forced me to build spiritual muscle in areas that needed to be built up... But again, I think it's positive if I look back now to where I am today. It was hard but I've learnt such a lot.' 
Through uncomfortable circumstances, Jenny said that she became aware of a new perspective and insight about herself and others (i.e.,such as increased empathy). She described the pandemic as God's training school, saying: 'Once I recognised that actually I could start to come out of it [the COVID-19 pandemic] and heal, and understand it... it was really helpful for my client work. So, you know God is good in that He's giving me more insight and I'm a believer in God training me from the inside out.'

The lockdown seems to have motivated participants to reassess all aspects of their lives. Olivia reflected on how she had developed a heightened sense of appreciation: 'I'd been mentally and spiritually exhausted... but it was also an experience that made me extremely humble and grateful for all the things that God has given me.'

\section{Religion and spirituality $(R / S)$ as a coping resource}

The third major theme is the role of religion and spirituality (R/S), employed by the participants to cope with the ongoing spiritual and psychosocial impacts of the pandemic. Despite the distractions to their normal religious and spiritual practices, as a result of these restrictions, participants talked about how their Christian faith and spirituality contributed important resources in coping with the difficulties.

\section{$R / S$ as a cognitive resource}

All the participants clearly said that their intrinsic religious beliefs and beliefs about suffering (also known as theodicies) provided cognitive understanding of the religious and existential dimensions of the pandemic, contributing to a sense of purpose, and meaning in their current challenging experiences.

Jenny shared how her belief that God compassionately shares in human suffering was enhanced, and that God sustains people with His presence through stressful times: 'I believe that God is suffering, and that God is there with us in our suffering. So, when people are sick, when people are struggling... I know that God is still in control and whatever happens, however bad it gets I know God is still in control.' Caroline spoke in a similar way, saying, 'I had a moment where it felt like fear and anxiety gripped me... but God is greater than what is around us. He comforts and protects us (C-6: 225227).'

\section{$R / S$ as a psychological resource}

Aside from the cognitive strategies, participants described the ways that they have stayed connected with God by involving themselves in prayer, Bible reading, and spiritual activities. They said that acquiring these coping skills ultimately aided their resilience throughout the pandemic. Interestingly, participants reported more frequent use of prayer than other religious practices in order to experience God's presence. For example, Jenny discussed the significance of her prayer life in enabling her to cope with the ongoing pandemic, saying, The prayer and coming before Him has been a key to sustaining me. It's what holds me and I'm not quite sure how people do without it. Prayer is a key part of my daily life.'

Prayer appeared to work in similar ways to psychotherapy, specifically through reflective processing. Simply talking about their life and struggles seemed to provide relief and promote 
psychological wellbeing (Jeppsen and Wooldridge, 2012). For example, Annie reflected on how she experienced God's presence through prayer, and she said it helped her to think more clearly. She noted, It's really helpful... I think when I pray... I feel relaxed and think more clearly. That's why when I'm stressed and worried about everything going on around me... I just want to rely on God.'

\section{$R / S$ as a social resource}

The third category is one of social support and social networks, the use of which seemed to lead to a reduction in pandemic-related stress on mental and physical health.

Annie noted that it was through engagement in online Bible study that she had access to social interaction: 'just doing the Alpha course recently... I feel a lot better knowing that I've been able to speak to people and be heard. It feels like you belong and that you are known.' Similarly, Jenny also stated that her religious involvement had brought tangible benefits during the pandemic period: 'It does help me because... people with similar priorities around me gives me strength. People to push me along and give me strength in everyday living.'

\section{Summary of findings}

The closure of churches and religious institutions, as a result of the pandemic, profoundly affected the way in which the participants practised their faith. Although they initially experienced feelings of sudden loss within their institutional religious lives, social connection and social support, all of them showed remarkable resilience in adapting to the barrage of challenges and staying connected with their faith communities. Interestingly, all the participants expressed feelings of significant spiritual growth through these challenging circumstances. Their Christian faith was a prominent factor that allowed them to develop refined coping mechanisms, functioning as a social resource for them to maintain their mental wellbeing throughout the lockdown periods especially. It helped them to make sense of what was happening and to find a renewed sense of meaning while adapting to the 'new normal'.

\section{Discussion}

Introduction

This study aimed to explore how Christian therapists experience and interpret the impact of COVID-19, on their faith and spirituality. The observed findings will further be discussed, relating back to the main research aims (Smith et al., 2012).

\section{Dealing with the feelings of sudden loss}

The pandemic has profoundly challenged the way in which religious and spiritual life is conducted (Lucchetti et al., 2020; Dein et al., 2020). Each of the participants reported that the Christian faith was at the centre of their lives. When the narratives touched on issues to do with the corresponding impacts on their faith and spirituality; 'a sudden sense of loss' seemed to be the dominant theme, affecting their spiritual and psychological wellbeing in a number of different ways. 
When the social distancing measures were first introduced nationally in the UK, the most significant change to the participants' faith and spirituality was the sudden loss of institutional religiosity (Lucchetti et al., 2020:6; Bentzen, 2020:4). Aside from the disruption to normal religious practices, participants' connections with others were abruptly fractured as a result of the public health controls, which resulted in the decline in interpersonal rapport within their support systems. Consequently, the loss and erosion of social connections and support networks became another loss that the participants had to accept as a part of this negative sequelae. In fact, churches provide not only a sense of belonging or connection but also a strong foundation of social support through the engendering of fellowship (VanderWeele et al., 2017:515). Undoubtedly, the closure of these sites of worship were considered to be particularly challenging and described as having a detrimental impact on psychological and spiritual wellbeing.

These findings are consistent with previous research, which highlights how experiencing situations of crisis and loss can result in corresponding knock-on effects to one's mental health (Brooks et al., 2020; Roy et al., 2020; Coppola, 2021). Additionally, the study corroborates the existing literature in the discourse, as shown by the fact that religious experiences of service attendance itself seemed to be powerfully related to the individual's spiritual and psychological wellbeing (Petts, 2014: 759; VanderWeele, 2017:521).

However, although the participants' experiences of relational losses tied to their individual faith communities were somewhat varied, the perceived value of these social relationships were substantial, which tended to have a greater impact on their wellbeing (Siedlecki et al., 2014:561562; Cooper et al., 2020:15-20). The findings provide a degree of insight into the correlation between social connectedness and psychological wellbeing, revealing that the meanings assigned to human interaction tended to directly influence an individual's susceptibility to stress (Cooper, 2020:21-23).

From a relational perspective, faith is experienced in relationships with others and God (Buber, 1990), and this engagement fulfils a basic psychological need for belonging (Baumeister and Leary,

1995:497). As such, it is unsurprising to see that the COVID-19 related restrictions that impeded this bond had a significant impact on their spiritual wellbeing. It also appears that face-to-face religious involvement itself contributes to this emotional support system for the participants through a variety of means (Koenig, 2012; Bentzen, 2020). Nevertheless, it is evident that additional research is necessary to better understand the implications of physical closeness during corporative religious practices, and to examine more closely the factors that connect mental health with the benefits of in-person services.

With regards to the religious and spiritual (R/S) struggles, the participants clearly stated that the stressors caused by the pandemic raised R/S struggles considerably, generating distressing emotions. Undoubtedly, the unprecedented global conditions could indeed be profoundly existential and a collectivistic experience that has come about due to the radical changes in the way we engage with the self, with others, and with the world (Huang et al., 2020; Maaravi et al., 2021).

The above findings are supported by existing precedent that traumatic stressors tend to increase the propensity of religious and spiritual struggles - the outcomes of which can vary significantly 
according to the individual (Exline and Rose, 2013; Desai and Pargament, 2015). Incorporating this into a clinical perspective, it is necessary to explore the degree to which the pandemic-related restrictions caused individuals to renegotiate the relationship with their faith on multiple domains (i.e.,spiritual, psychological, and social). Indeed, particularly for those with strong religious values that are central to their worldviews, wellbeing may be affected more significantly through these spiritual struggles (Lee 2020; Dein et al., 2020). Hence, consideration of these ongoing tensions in therapy is necessary, with caution. Sensitivity is paramount during such discussions with clients, whether religious faith is considered as a means of obtaining comfort, or whether they engage with faith as both a resource and a challenge. Additionally, there is a need to develop more refined therapy strategies, and existing techniques should further be tailored to consolidate the ramifications of COVID-19.

\section{Adaptation and spiritual growth}

This study has shown that a noteworthy repercussion of this pandemic has been the further development of latent procedures in individual or private religious practices (Koenig, 2020; Galea et al., 2020). Religious people, naturally, have been compelled to adapt their practices and behaviour in order to preserve their wellbeing (Simonsen et al., 2018; Villani et al., 2019).

Although this new virtual normality contributed to the eventual re-connecting of people in shared worship and fellowship, the findings show that this situation may also have led people to distance themselves from their faith community, and to challenge existing religious beliefs or preconceptions (Parish, 2020:1). Furthermore, even for those continuing to participate in their faith communities remotely, individualised religious practices (e.g., reading the Bible or praying) seemed to be more frequent and intensified than when participating in institutional rituals or official meetings in faith communities. With regards to the religious resources, participants reported that they preferred to seek out their own resources rather than those offered by their respective churches.

The reason for this tendency is likely to be attributable to a decrease in levels of engagement with institutional religious activities (Parish, 2020:2). In addition to this, it could be the fact that many resources suddenly became available during the lockdown period, as nearly all the Christian faithbased institutions began to offer online access to their activities, especially for those involving interactive communication (e.g., Zoom) and live-streaming (Church of England, 2020; Glatz, 2020; Delap, 2020). However, it is acknowledged that this study is situational within the cultural context of participants who are computer literate. As such, it is necessary to note that online religious resources or activities might not be regularly accessible to all members of the faith community, especially for those who cannot access computers or the internet (Gasser et al., 2020:425; Nye and Lobley, 2020: 17). This can be explained through Campbell's study that the transfer of churches to online forums may not only deny access to a dynamic and changing process, determined by individual needs or choices, but also deny members to the various religious practices that individuals participate in, either in groups or individually (Campbell, 2012 \& 2020). Taken together, it is evident from this study that the efficacy of virtual methods was at best sporadic, especially in relation to spiritual reflection. 


\section{Spiritual growth}

A similar pattern of connections between religious and spiritual (R/S) struggles and spiritual growth is widely noted in previous studies of mental health during times when unpredictable events have become the norm (Desai \& Pargament, 2015: 42; Stauner et al., 2016: 64; Rudolfsson \& Tidefors, 2014). This study also found that the COVID-19 pandemic seemed to function as a catalyst for spiritual growth since it brought the opportunity to gain a renewed and strengthened faith through one's engagement with R/S derived struggles.

Among the various religious factors that contributed to spiritual growth in the participants, it is important to note that the most common feature appears to have been the increase in private religious activities, such as prayer and Bible study. This finding is intriguing as there is a tendency in previously conducted studies to denote religious service attendance as the most important variable driving spiritual growth (Li et al., 2016: 8; Chen et al., 2020: 2030; VanderWeele, 2020: 85). Historically, religious practice is mostly associated with organised practice and resources (Austin et al., 2018:1). However, in the context of COVID-19, social restrictions prevented routine religious attendance and for this reason private or online religious involvement seemed to offer the same benefits found in institutional religiosity (Dolcos et al., 2021).

\section{Religion and Spirituality (R/S) as a coping resource}

The present study exhibited a number of compelling insights. First and foremost, it could be observed that the participants opted to turn to God to deal with the stressors that they were facing during the pandemic. In addition, it was clear that their Christian faith had a remarkable influence on their mental health (Hart \& Koenig, 2020; Koenig, 2020). Although such results have been widely showcased in pre-existing research (Pargament, 1997; Park et al., 2011; Exline, 2013), very few studies have investigated the way in which the Christian faith and spirituality operates in this context to minimise the effect of external traumas and feelings of social isolation (Koenig, 2020; Pirutinsky et al., 2020). Therefore, clarification of these issues is necessary, as it is a core aspect that informs both general counselling practices and the counselling procedures of religious clients (Singh \& Madan, 2017:342). Christian faith as a religious coping mechanism was further evidenced throughout this study, which showed that intrinsic religiosity and faith in God's plan in suffering (coupled with religious involvement) function primarily as a cognitive, psychological, social, and relational resource for the participants that supports their spiritual and psychological wellbeing.

\section{$R / S$ as a cognitive resource: intrinsic beliefs and theodicies}

Consistent with previous research, the findings indicated that R/S provided participants with a source of cognition and attitudes that reframed the pandemic into relatively less stressful frames ('positive cognitive reappraisal'; Thomas and Savoy, 2014: 88; Dolcos et al., 2020), and facilitated the search for meaning and purpose (Rosmarin and Koenig, 2020; Pirutinsky et al., 2020) by increasing spiritual and social connections (Lim \& Putnam, 2010: 914) while developing self-control (McCullough and Willoughby, 2009: 69).

Several authors thus far have established the importance of religion for 'meaning making' and helping individuals endure and even grow through times of suffering (Park, 2010: 257; Hall et al., 2018: 77). This study also supports the interpretation that believing in God's involvement in the 
pandemic may be positively correlated with a sense of 'meaning making' in practice. Moreover, the participants' inherent belief in God's benevolent involvement further seemed to reinforce their trust in God and promote increased resilience within themselves. These findings again correspond with that of existing studies; the intrinsic belief that ties less stress with positive religious coping has proven to be one of many ways through which God achieves His purpose (Hovey et al., 2014; Villani et al., 2019; Pirutinsky et al., 2020).

\section{$R / S$ as a psychological coping resource}

Aside from cognitive strategies, the findings suggest that the participants' positive beliefs about God represented a basic strength and a resource that enabled them to better manage their psychological distress in times of hardship. Existing theories and academics within the discourse have often theorised that people are more inclined to use prayer as a coping mechanism when the problems are more severe, or indeed when the other resources have been exhausted (McCullough \& Larson, 1999; Masters and Spielmans, 2007: 329; Dezutter et al., 2011: 542).

Consistent with current academic theory (Masters and Spielmans, 2007; Dezutter et al., 2011), the study showed that prayer was most frequently used in religious practice among all the participants and that it seemed to help them develop a deeper awareness of God's presence. Consequently, this appeared to enhance their psychological robustness. Particularly, prayer reflecting on 'who God is' seemed to have been effectively used by all of the participants when coping with COVID19-related stress. From a cognitive perspective, it can also be argued that mentally focusing on the character of God as a loving and protective figure could also serve as a valuable resource. Shifting the focus away from the pandemic and relinquishing all control to God would give them the added liberty of spiritual solace (Krause, 2003; Masters \& Spielmans, 2007; McLaughlin et al., 2013).

In addition to the importance of prayer content (e.g., reflecting on the character of God), the participants' experiences indicate that their prayer life needs to be incorporated into their religious meaning system before it functions as a buffer for the negative thoughts that come with thinking about the pandemic (Park, 2006; Dezutter et al., 2011; Krok, 2014). It is possible that individuals who are intrinsically motivated by their faith may primarily cope with their stressors by engaging with their religious meaning systems through prayer, which in turn helps them to reinterpret situations in a more positive and meaningful light (Masters and Spielmans, 2007; Dezuttere et al., 2011). Therapists should also be alert to how clients' religious meanings and attributions could be both a resource and a potential source of struggle during periods of intensified stress.

\section{$R / S$ as a social coping resource}

All in all, this study corroborates the preceding research, which indicates that religion can be both a social and relational resource, differentiated by interpretation (Koenig, McCullough, \& Larson, 2001; Holt et al., 2019).

Contemporary insight identifies that attending religious activities and engaging in religious behaviour prospectively predicts an increase in social support over time (Strawbridge et al, 2001; Holt et al., 2014), and that social relationships are a mechanism underlying the effect of religious practices on wellbeing (Koenig et al., 2012; Holt et al., 2014; Merino, 2014). Although such results have been extensively discussed throughout the course of the past decade especially, few studies 
(Vilog et al., 2020; Dutra \& Rocha, 2021) have since assessed these considerations in the context of the current pandemic. In support of previous literature (Holt et al., 2014; Vilog et al., 2020), the present study shows evidence of the same pathway via virtual means of social support. Historically, religious activities often occur within a social context. It is conceivable that for people living with enforced social isolation, especially during pandemic times, their faith community may provide the only viable sense of social support, satisfying the need for belonging that contributes to a positive mental outlook (Koenig et al., 2012; Nica, 2019; Weinberger-Litman et al., 2020).

In this sense, the faith community appears to be more than a space of worship, it's also a social juncture that strengthens participants' sense of connection during such periods of social isolation. These places maintain their own sense of sacred agency that ultimately allows for a more positive psychological attitude (Fagan et al., 2012; Weinberger-Litman et al., 2020).

\section{Limitations}

This IPA study yielded detailed and rich outcomes of how the therapists grappled with their faith and spirituality throughout the pandemic period. Yet, it is nonetheless the case that the observed findings need to be interpreted with care and with consideration of the following limitations.

Firstly, the study, while homogeneous, had an imbalance of represented religions, with all the participants being from evangelical church backgrounds. As such, it cannot be regarded as being representative either of the entire population or of Christian therapists in general. Additionally, all the participants in the sample group were female Christian therapists, who agreed with the notion that the Christian faith was at the centre of their lives. Previous research indicates that women tend to be more religious than men (Forlenza and Vallada, 2018: 1741; Kowalczyk et al, 2020: 2676). This could have impacted the high levels of spiritual growth and positive religious coping evidenced in the study. However, it is crucial to note that understanding representativeness was never the objective of this IPA study, which instead emphasises an ideographic and phenomenological approach to gain a deeper insight into the participants' lived experiences (Smith et al., 2012).

Also, as reported previously, religious coping strategies can have negative and positive influences on mental health. However, the current study did not highlight the negative aspects of coping among the participants. While the IPA does not deviate from making generalisations, it is committed towards analysing individuals' subjective accounts rather than the formulation of objective narratives (Smith et al., 2012; Flowers et al., 1999). Conclusions drawn are therefore specific to this particular group as mentioned, and generalisations should be approached with caution.

\section{Recommendations for Future Research}

The study was conducted during the third national lockdown between February-March 2021 in the UK. During a pandemic that had not previously been experienced by anyone involved. While this implies that this research is unlikely to ever be replicated in the same circumstances, further studies would be needed to analyse the long-term impacts of COVID-19 on the Christian faith and spirituality. 
Several participants spoke directly about how their professional role as a therapist had been affected by COVID-19, as well as speaking in the position of being clients themselves. Many were keen to forget the disastrous circumstances they initially found themselves in, at varying stages of the pandemic. Future research could perhaps explore the overarching impact of COVID-19 on the administration of therapeutic practices.

\section{Conclusion}

This body of research sought to explore how Christian therapists experience and interpret the impact of COVID-19 through their faith and spirituality.

The observed findings illustrated that the closure of churches had lasting effects on the spiritual life of the participants, resulting in a sudden loss of institutional religious life, social connections, and social support systems. Despite such difficulties, all the participants demonstrated marked resilience and the ability to adapt to the pandemic life. Engaging in virtual religious activities and connecting with their faith and religious communities, gave them the means to preserve their religious livelihoods. Noteworthy consequences of the pandemic were that it led to the acceleration of pre-existing individualised religious practices. Interestingly, each of the participants could relate to an instance of significant spiritual growth through the challenging circumstances. Christian faith does appear to constitute a key resource in coping with pandemic-related stress, functioning primarily as a cognitive, psychological, social, and relational resource.

Ultimately, in spite of the limitations of qualitative research, the current study is among the first to explore the lived experiences of therapists in relation to the consequences of COVID-19 on Christian faith and spirituality. Given the potential for major life crises to shake people deeply both psychologically and spiritually, the pandemic demonstrated the pressing need for therapists to address clients' religious and spiritual issues directly and to consider spiritual wellbeing as a critical component of holistic care (Ellison and Lee, 2010; Krause, 2015; Bell et al., 2020:1). As such, it is with a degree of optimism that this research was conducted, in the hope that it would supplement the resources of therapists that may result in more positive clinical outcomes going forward.

\section{References}

Austin, P., Macdonald, J., \& MacLeod, R. (2018) Measuring spirituality and religiosity in clinical settings: A scoping review of available instruments, Religions, 9 (70), pp. 1-14.

Bare, D. (2020) How embodied is "the body of Christ?" COVID-19 and Christian corporeality. In. Campbell, H. (ed.) Religion in Quarantine: The Future of Religion in a Post-Pandemic World. Network for New Media, Religion \& Digital Culture Studies, pp. 36-38.

Baumeister, R. F. \& Leary, M. R. (1995) The need to belong: Desire for interpersonal attachments as a fundamental human motivation, Psychological Bulletin, 117 (3), pp. 497-529. [online] Available at: https://www.researchgate.net/profile/Mark-Leary2/publication/15420847 The Need to Belong Desire for Interpersonal Attachments as a Fund amental Human Motivation/links/5b647053aca272e3b6af9211/The-Need-to-Belong-Desire-forInterpersonal-Attachments-as-a-Fundamental-Human-Motivation.pdf [Accessed 1 March 2021] 
Exploring Christian therapists' experience of the Impact of the COVID-19 pandemic on their faith and spirituality: an interpretative phenomenological analysis

Bentzen, J. (2020) In crisis, we pray: Religiosity and the COVID-19 pandemic [Unpublished manuscript, pp. 1-44. [online] Available at: https://www.researchgate.net/profile/]eanetBentzen/publication/343627578_In_Crisis_We_Pray_Religiosity_and_the_COVID19_Pandemic/links/5f34e703458515b7291bf329/In-Crisis-We-Pray-Religiosity-and-the-COVID-19Pandemic.pdf [Accessed 28 Jan. 2021].

Holy Bible: King James Version.

Buber, M. (1970) / and Thou. London: Bloomsbury Academic.

Campbell (2012) Understanding the relationship between religion online and offline in a Network Society, Journal of the American Academy of Religion, pp. 1-30. [online] Available at:

https://www.researchgate.net/profile/Heidi-Campbell-

8/publication/261967407 Understanding the Relationship between Religion Online and Offlin e in a Networked Society/links/569eb6cc08ae21a56424ec71/Understanding-the-Relationshipbetween-Religion-Online-and-Offline-in-a-Networked-Society.pdf [Accessed 07 April 2021]

Campbell H (2020) Religion embracing and resisting cultural change in a time of social distancing. In: Religion in quarantine: the future of religion in a post-pandemic world. Network for New Media, Religion \& Digital Culture Studies, pp. 9-14. [online] Available at: https://commons.stmarytx.edu/cgi/viewcontent.cgi?article=1000\&context=instruction [Accessed 02 Feb. 2021].

Chen, Y., Kim, E. S., Koh, H. K., Frazier, A. L., and VanderWeele, T. J. (2019b) Sense of mission and subsequent health and well-being among young adults: an outcome-wide analysis. Am. J. Epidemiol. 188, pp. 664-673. doi: 10.1093/aje/kwz009. [online] Available at: https://academic.oup.com/aje/article/188/4/664/5288559 [Accessed 07 March 2021]

Chen, Y., Kim, E., \& VanderWeele, T. (2020) Religious-service attendance and subsequent health and well-being throughout adulthood: evidence from three prospective cohorts, International Journal of Epidemiology, 49 (60), pp. 2030-2040. [online] Available at: https://academic.oup.com/ije/article/49/6/2030/5892419 [Accessed 12 April 2021]

Church of England (2020) Coronavirus Covid-19 Guidance for Parishes in Holy Week. [online] Available: https://www.churchofengland.org/more/media-centre/coronavirus-covid-19-guidanceparishes/holyweek-and-easter-2020 [Accessed on 20 Dec. 2020]

Cooper, A. B., Pauletti, R. E., \& DiDonato, C. A. (2020) You, me, and no one else: Degree of social distancing and personality predict psychological wellness and relationship quality during the COVID-19 Pandemic, Psychology, pp. 1-27. [online] Available at: https://psyarxiv.com/w6dru/ [Accessed 07 June 2021]

Coppen, L. (2020) Will coronavirus hasten the demise of religion - or herald its revival? The Spectator. [online] Available at: https://www.spectator.co.uk/article/will-coronavirus-cause-areligious-resurgenceor-its-ruination. [Accessed 12 March 2021]

Coppola, I., Rania, N., Parisi, R., \& Lagomarsino, F. (2021) Spiritual well-being and mental health during the COVID-19 pandemic in Italy, Frontiers in Psychiatry, 12, pp. 1-15. 
Counted, V., Pargament, K. I., Bechara, A. O., Joynt, S., \& Cowden, R.G. (2020) Hope and well-being in vulnerable contexts during the COVID-19 pandemic does religious coping matter? The Journal of Positive Psychology, pp. 1-12.

Dein, S., Loewenthal, K., Loewenthal, K., Lewis, C., \& Pargament, K. (2020) COVID-19, mental health and religion: an agenda for future research, Mental Health, Religion \& Culture, 23 (1), pp.1-9. [online] Available at: https://www.tandfonline.com/doi/full/10.1080/13674676.2020.1768725. [Accessed 11 Nov. 2020].

Delap, D (2020) How we shared the bread and wine on Zoom, The Church Times. [online] Available: https://www.churchtimes.co.uk/articles/2020/17-april/comment/opinion/how-we-shared-thebreadand-wine-on-zoom [Accessed 21 March 2021]

Desai, K. M., \& Pargament, K. I. (2015). Predictors of growth and decline following spiritual struggles, The International Journal for the Psychology of Religion, 25 (1), pp. 42-56.

Dezutter, J., Wachholtz, A., \& Corveleyn, J. (2011) Prayer and pain: the mediating role of positive reappraisal, J Behav Med 34, pp. 542-549.

Doehring, C. (2020) Coping with moral struggles arising from coronavirus stress: Spiritual self-care for chaplains and religious leaders. Chaplaincy Innovation Lab. [online] Available at: https:// chaplaincyinnovation.org/wp-content/uploads/2020/03/Doehring-2020-Coping-with-moralstruggles-arising-from-coronavirus-stress.pdf [Accessed 1 Nov. 2020]

Dolcos, F. Hohl, K., Hu, Y., \& Dolcos, S. (2020) Religiosity and resilience: Cognitive reappraisal and coping self-efficacy mediate the link between religious coping and well-being, Journal of Religion and Health, pp. 1-14. [online] Available at: https://link.springer.com/article/10.1007/s10943-02001160-y [Accessed 20 Dec. 2020].

Dubey, S., Biswas, P., Ghosh, R., Chatterjee, S., Dubey, J.M., Chatterjee, S. \& Lavie, C. (2020) Psychosocial impact of COVID-19, Diabetes \& Metabolic Syndrome: Clinical Research \& Reviews (14), pp. 770-789. [online] Available at: https://www.ncbi.nlm.nih.gov/pmc/articles/PMC7255207/ [Accessed 06 March. 2020].

Dutra, C. D. \& Rocha, H. (2021) Religious support as a contribution to face the effects of social isolation in mental health during the pandemic of COVID-19, Journal of Religion and Health, 60, pp. 99-111. [online] Availabe at: https://www.ncbi.nlm.nih.gov/pmc/articles/PMC7786321/ [Accessed 07 March 2021].

Ellison, G. and Lee. J (2010) Spiritual struggles and psychological distress: Is there a dark side of religion? Social Indicators Research 98 (3), pp. 501-517.

Exline, J. J. (2013) Religious and spiritual struggles. In K. I. Pargament, J. J. Exline, \& J. W. Jones (Eds.), APA Handbook of Psychology, Religion, and Spirituality (vol. 1): Context, Theory, and Research, pp.459475. Washington, DC: American Psychological Association.

Exline, J. J., \& Rose, E. (2013) Religious and spiritual struggles. Handbook of the Psychology of Religion and Spirituality, 2nd ed., pp. 379-398. New York, NY: Guilford Press. 
Exline, J. J., Hall, T. W., Pargament, K. I., \& Harriott, V. A. (2017) Predictors of growth from spiritual struggle among Christian undergraduates: Religious coping and perceptions of helpful action by God are both important. Journal of Positive Psychology, 12 (5), pp. 501-508.

Exline, J. J., Pargament, K. I., Grubbs, J. B., \& Yali, A. M. (2014) The religious and spiritual struggles scale: Development and initial validation, Psychology of Religion and Spirituality, 6 (3), pp. 208-222. https://doi.org/10.1037/a0036465

Fagan, D.M., Kiger, A., \& Teijlingen, E. (2012) Faith communities and their assets for health promotion: the view from health professionals and faith leaders in Dundee, in Scotland, Glob Health Prompt 19 (2), pp. 27-36

Fisher, E. B., Miller, S. M., Evans, M., Luu, S. L., Tang, P. Y., Dreyer Valovcin, D., et al. (2020) COVID19, stress, trauma, and peer support-observations from the field. Transl. Behav. Med. 10, pp. 503505. doi: $10.1093 /$ tbm/ibaa056

Forlenza, O. V., \& Vallada, H. (2018) Spirituality, health and well-being in the elderly. International Psychogeraitrics, 30, 741-1742.

Galea S., Merchant R. M., Lurie N. (2020) The mental health consequences of COVID-19 and physical distancing: The need for prevention and early intervention. JAMA Internal Medicine, 180 (6), pp. 817-818.

Garner D (2020) The distanced church: Pragmatism, creativity, and rhythms In. Campbell H (ed.) Religion in Quarantine: The Future of Religion in a Post-Pandemic World. Network for New Media, Religion \& Digital Culture Studies, pp. 55-58. [online] Available at: https://jliflc.com/wpcontent/uploads/2020/06/Distanced-Church-PDF-landscape-FINAL-version.pdf [Accessed 03 March 2021]

Gasser, U, Lenca, M., Scheibner, J. Sleigh, J., \& Vayena, P. (2020) Digital tools against COVID-19: taxonomy, ethical challenges, and navigation aid, The Lancet Digital Health, 2 (8), pp. 425-434.

Gecewicz, C. (2020) Few Americans say their house of worship is open, but a quarter say their faith has grown amid pandemic. Pew Research Center, April 30th. [online] Available at: https://www.pewresearch.org/fact-tank/2020/04/30/few-americans-say-their-houseof-worship-isopen-but-a-quarter-say-their-religious-faith-has-grown-amidpandemic/. [Accessed 18 Jan 2021]

Glatz, C (2020) Vatican reveals huge online growth over Easter. The Tablet. [online] Available at: https://www.thetablet.co.uk/news/12779/Vatican-reveals-huge-online-growth-over-easter [Accessed 06 Jan 2021].

Hamouche, S. (2020) COVID-19 and employees' mental health: Stressors, moderators and agenda for organizational actions. Emerald Open Research, 2(15), pp. 1-15. https://doi.org/10. 35241/emeraldopenres.13550.1 [online] Available at: https://www.ncbi.nlm.nih.gov/pmc/articles/ PMC7342058/ [Accessed 07 April 2021].

Hart C. W., \& Koenig H. G. (2020) Religion and health during the COVID-19 pandemic. Journal of Religion and Health, 59 (3), pp. 1141-1143. 
Hodge, D. R. (2006) Spiritually modified cognitive therapy: A review of the literature. Social Work, 51 (2), pp. 157-166.

Holmes, E., O'Connor, R., Perry, H., Tracey, I., Wessely, S., Arseneault, L., \& Bullmore, E. (2020) Multidisciplinary research priorities for COVID-19 pandemic: A call for action for mental health science, The Lancet Psychiatry, pp. 47-560 [Advance online publication]. http://dx.doi.org/10 .1016/S2215-0366(20)30168-1 Available at: https://www.thelancet.com/journals/lanpsy/article/ PIIS2215-0366(20)30168-1/fulltext [Accessed 17 Feb 2021]

Holt, C., Clark, E., \& Roth, D. (2017) Positive and Negative Religious Beliefs Explaining the Religion Health Connection Among African Americans, Int J Psychol Relig. 24 (4), pp. 311-331, [online] Available at: https://www.ncbi.nlm.nih.gov/pmc/articles/PMC5441393/ doi:10.1080/10508619. 2013.828993 [Accessed 06 Nov. 2020].

Holt, C., Roth, D. Hwang, J. \& Clark, E. (2019) Role of religious social support in longitudinal relationships between religiosity and health realted outcomes in African American, J Behav Med, 41(1), pp. 62-73 [online] Available at: https://www.ncbi.nlm.nih.gov/pmc/articles/PMC5766361/ [Accessed 03 March 2021]

Holt, C. L., Schulz, E., Williams, B. R., Clark, E. M., \& Wang, M. Q. (2014) Social support as a mediator of religious involvement and physical and emotional functioning in a national sample of AfricanAmericans. Mental Health, Religion \& Culture, 17 (4), pp. 421-435. https://doi.org/10.1080/13674676. 2013.82495

Hook, J. N., Worthington Jr, E. L., Davis, D. E., Jennings II, D. J., Gartner, A. L., \& Hook, J. P. (2010) Empirically supported religious and spiritual therapies. Journal of Clinical Psychology, 66 (1), pp.4672. [online] Available at https://onlinelibrary.wiley.com/doi/abs/10.1002/jclp.20626 [Accessed 02 May 2021].

Hovey, J. D. Hurtado, G., Lori, R. Morales, A. \& Seligman, L. D. (2014) Religion-Based Emotional Social Support Mediates the Relationship between Intrinsic Religiosity and Mental Health, Archives of Suicide Research, 18, pp. 376-391. [online] Available at: https://www.jhoveyphd.com/uploads/1/2/7/2/127269752/hovey 2014a.pdf [Accessed 17 April 2021].

Huang, F. Ding, H., Liu, Z., Wu, P., Zhu, M., Li, A. \& Zhu, T. (2020) How fear and collectivism influence public's preventive intention towards COVID-19 infection: a study based on big data from the social media, BMC Public Health, 20 (1707), pp. 1-9.

Jaspal, R., \& Lopes, B. (2021) Discrimination and mental health outcomes in British Black and South Asian people during the COVID-19 outbreak in the UK, Mental Health, Religion and Culture, 24 (1), pp. 80-96 Available at: https://www.researchgate.net/publication/347257053 Discrimination and mental health outco mes in British Black and South Asian people during the COVID-19 outbreak in the UK [Accessed 07 May 2021].

Kanter, J., \& Manbeck, C. (2020) Covid-19 could lead to an epidemic of clinical depression, and the health care system is not ready for that either. [online] Available at: 
https://theconversation.com/covid-19-could-leadto-an-epidemic-of-clinical-depression-and-thehealth-care-system-isntready-for-that-either-134528 [Accessed 22 November 2021].

Koenig, H. G. (2012) Religion, Spirituality, and Health: The Research and Clinical Implications, Psychiatry, pp. 1-33. [online] Available at: https://www.ncbi.nlm.nih.gov/pmc/articles/PMC3671693/[ Accessed 16 March 2021].

Koenig H. G. (2020) Maintaining health and well-being by putting faith into action during the COVID-19 pandemic, Journal of Religion and Health, 59 (5), pp. 2205-2214.

Koenig, H. G., King, D. E., \& Carson, V. (2012) Handbook of Religion and Health (2nd ed.). Oxford, UK: Oxford University Press.

Koenig, H. G., McCullough, M. E., \& Larson, D. B. (2001) Handbook of Religion and Health. New York: Oxford University Press.

Koenig, H. G., Al-Zaben, F. \&Tyler J. VanderWeele, T. J. (2020) Religion and psychiatry: Recent developments in research. BJPsych Advances, pp.1-11.

Kowalczyk, O., Roszkowski, K., Montane, X., Pawliszak, W., Tylkowski, B., \& Bajek, A. (2020) Religion and faith perception in a pandemic of COVID-19, Journal of Religion and Health 59, pp.2671-2677.

Krause, N. (2004) Assessing the relationships among prayer expectancies, race, and self-esteem in late life. Journal for the Scientific Study of Religion, 43, pp. 395-408. [online] Available at: https://onlinelibrary.wiley.com/doi/abs/10.1111/j.1468-5906.2004.00242.x [Accessed 05 May 2021].

Krause (2015) Religious doubt, helping others, and psychological well-being. Journal of Religion and Health 54 (2), pp. 745-58.

Krok, D. (2014) The religious meaning system and subjective well-being, Psychology of Religion, 36, pp. 253-273. [online] Available at: https://www.researchgate.net/profile/Dariusz-Krok3/publication/280055185 The Religious Meaning System and Subjective Well-

Being/links/5bd41898a6fdcc3a8da93053/The-Religious-Meaning-System-and-Subjective-WellBeing.pdf [Accessed 07 June 2021].

Lee, S. A. (2020) Coronavirus anxiety scale: A brief mental health screener for COVID-19 related anxiety, Death Studies, 44 (7), pp. 393-401. [online] Available at: https://www.tandfonline.com/doi/full/10.1080/07481187.2020.1748481

https://doi.org/10.1080/07481187.2020.1748481 [Accessed 10 Nov. 2020].

Li, S., Okereke, O. I., Chang, S.-C., Kawachi, I., \& VanderWeele, T. J. (2016) Religious service attendance and depression among women - a prospective cohort study, Annals of Behavioral Medicine, 50, pp. 876-884.

Li, Z, Ge, J, Yang, M, Feng, J., Qiao, M, JiangR, et al. (2020) Vicarious traumatization in the general public, members, and non-members of medical teams aiding in COVID-19 control. Brain Behav Immun [Epub ahead of print]. Available at: https://www.researchgate.net/publication/339670646_Vicarious_traumatization_in_the_general_ 
public members and non-members of medical teams aiding in COVID-19 control [Accessed 11 Nov.2020].

Lim, C (2015) Religion and Subjective Well-Being Across Religious Traditions: Evidence from 1.3 million Americans, Journal for the Scientific Study of Religion, 54 (4), pp. 684-701. [online] Available at: https://onlinelibrary.wiley.com/doi/abs/10.1111/jssr.12232 [Accessed 24 Oct. 2020].

Lim, C., \& Putnam, R. D. (2010) Religion, social networks, and life satisfaction, American Sociological Review, 75(6), pp. 914-933.

Lim, C., Sim, K., Renjan, V., Sam, H. F., \& Quah, S. L. (2014) Adapted cognitive-behavioral therapy for religious individuals with mental disorder: A systematic review, Asian Journal of Psychiatry, 9, pp. 3-12.

Lopes, B. C. \& Jaspal, R. (2020) Understanding the Mental Health Burden of COVID-19 in the United Kingdom, Psychologicla Trauma Theory, Research, Practice and Policy. 12 (5), pp. 465-467.

Lucchetti, G., Goes, L. G. Amaral, S. G. Ganadjian, G. T. Andrade, I. Almeid, P.O. Carmo, V. M. \& Manso, M. E. G. (2020) Spirituality, religiousiy and the mental health consequencs of social isolation during COVID-19 pandemic, International Journal of Social Psychiatry, 1 (8), pp. 1-8. [online] Available at: https://journals.sagepub.com/doi/pdf/10.1177/0020764020970996 [Accessed 05 March 2021].

Maaravi, Y., Levy, A., Gur, T., Confino, D., \& Segal, S. (2021) "The tragedy of the commons": How individualism and collectivism affected the spread of the COVID-19 pandemic, Frontiers in Public Health,9, pp. 1-6. [online] Available at: https://www.ncbi.nlm.nih.gov/pmc/articles/PMC7905028/ [Accessed 09 May 2021].

Mantyla, K. (2020) Perry Stone claims America's coronavirus outbreak is a 'reckoning' for allowing abortion and gay marriage, Richard Dawkins Foundation for Reason and Science. [online] Available at: https://www. richarddawkins.net/2020/03/perry-stone-claims-americas-coronavirus-outbreakis-a-reckoning-for-allowing- abortion-and-gay-marriage/ [Accessed 1 Nov. 2020].

Masters, K., \& Spielmans, G. (2007) Prayer and health: Review, meta-analysis, and research agenda, Journal of Behavioral Medicine, 30, pp. 329-338. [online] Available at: http://www.patriziotressoldi.it/cmssimpled/uploads/includes/MetalntercPrayerMasters07.pdf[Ac cessed 09 June 2021].

McConnell, K. M., Pargament, K. I., Ellison, C. G., \& Flannelly, K. J. (2006) Examining the links between spiritual struggles and symptoms of psychopathology in a national sample, Journal of Clinical Psychology, 62, pp. 1469-1484. https://doi.org/10.1002/jclp.20325.

McCullough, M., \& Larson, D. (1999) Prayer. In W. R. Miller (Ed.), Integrating spirituality into treatment, pp. 85-110. Washington: American Psychological Association.

McCullough, M. E., \& Willoughby, B. L. (2009). Religion, self-regulation, and self-control: Associations, explanations, and implications, Psychological Bulletin, 135 (1), pp. 69-93.[online] Available at: $\quad$ https://www.researchgate.net/profile/Michael-Mccullough- 
7/publication/24001207 Religion Self-Regulation and Self-

Control Associations Explanations and Implications/links/00463525bc60172b69000000/Religion -Self-Regulation-and-Self-Control-Associations-Explanations-and-Implications.pdf [Accessed 09 May 2021].

McLaughlin, B., Yoo, W., D'Angelo, J., Tsang, S., Shaw, B \& Shah, D. (2013) It is out of my hands: How deferring control to God can decrease quality of life for breast cancer patients, Psycho-Oncology. 22, pp. 2747-2754. Doi:10.1002/pon.3356. [PubMed: 23913722]

Merino, S. M. (2014) Social support and the religious dimensions of close ties, Journal for the Scientific Study of Religion, 53 (3), pp. 595-612. https://doi.org/10.1111/jssr.12134

Meza, D. (2020) In a pandemic are we more religious? Traditional practices of Catholics and the COVID-19 in Southwestern Colombia, International Journal of Latin American Religions, pp. 1-17 https://doi.org/10.1007/s41603-020-00108-0

Nica, A. (2019) Exiters of Religious fundamentalism: reconstruction of social support and relationships related to well-being, Mental Health, Religion \& Culture, 22 (5), pp. 543-556 [online] Available at: https://pdxscholar.library.pdx.edu/open_access_etds/4404/ [Accessed 09 June 2021].

Noth, I., \& Lampe, J. (2020) Religious and spiritual conflicts: A psychological perspective, Pastoral Psychology 69, pp. 135-147 [online] available at: Available at: http://web.b.ebscohost.com. [Accessed 07 April 2021].

Nye, C., \& Lobley, M. (2020) COVID-19, Christian Faith and Wellbeing, Centre for Rural Policy Research, University of Exeter. [online] Available at: https://www.exeter.ac.uk/news/homepage/title_823020_en.html [Accessed 28 Nov. 2020].

Ornell, F., Halpern, S., Kessler, F., \& Narvaez, J.(2020) The impact of the COVID-19 pandemic on the mental health of healthcare professionals, [online] available at: https://www.scielosp.org/article/csp/2020.v36n4/e00063520/ [Accessed 1 Nov. 2020]

Pargament, K. I. (1997) The Psychology of Religion and Coping: Theory, Research, and Practice. New York: The Guilford Press.

Pargament, K. I., \& Ano, G. G. (2006) Spiritual resources and struggles in coping with medical illness. Southern Medical Journal, 99 (10) , pp. 1161-1162. https://doi.org/10.1097/01.smj. 0000242847.40214.b6

Pargament, K. I. Lomax, J., Mcgee, J. S., \& Fang, Q. (2014) Sacred moments in psychotherapy from the perspectives of mental health providers and clients: Prevalence, predictors, and consequences, Spirituality in Clinical Practice 1 (4), pp. 248-262. [online] Available at: http: http://web.b.ebscohost.com [Accessed 07/11/2020]. [Accessed 22 Oct. 2020].

Pargament, K. I., Mahoney, A. E., \& Shafranske, E. P. (2013) APA Handbook of Psychology, Religion, and Spirituality (Vol 2): An Applied Psychology of Religion and Spirituality. New York: American Psychological Association. 
Pargament, K.I, Wilt, J. A. Exline, J. J. Grubbs, J. B. \& Park, C. L. (2016) God's role in suffering: Theodicies, divine struggle, and mental health, Psychology of Religion and Spirituality 8 (4), pp. 352362.

Parish, H. (2020) The absence of presence and the presence of absence: social distancing, sacraments, and the virtual religious community during the COVID-19 pandemic, Religious, 11 (276), pp. 1-13.

Park, C. (2006) Exploring relations among religiousness, meaning, and adjustment to lifetime and current stressful encounters in later life, Anxiety, Stress, and Coping, 19, pp. 33-45.

Park, C. L. (2010) Making sense of the meaning literature: An integrative review of meaning making and its effects on adjustment to stressful life events, Psychological Bulletin, 136 (2), pp. 257-301. doi:10. 1037/a0018301.

Park, C. L., Wortmann, J. H., \& Edmondson, D. (2011) Religious struggle as a predictor of subsequent mental and physical well-being in advanced heart failure patients, Journal of Behavioral Medicine, 34 (6), pp. 426-436. https:// doi.org/10.1007/s10865-011-9315-y.

Petts, R. J. (2014) Family, religious attendance, and trajectories of Ppychologial well-being among youth, Journal of Family Psychology, 28 (6), pp. 59-768.

Pew Research Center (2020) Most Americans say coronavirus outbreak has impacted their lives. [online] Available at: https://www.pewsocialtrends.org/2020/03/30/most-americans-saycoronavirus-outbreak-has-impacted-their-lives/ [Accessed 27 Oct. 2020].

Pew Research Center (2021) More Americans than People in other Advanced Economies says COVID19 Has Strengthened Religious Faith. [online] Available at: https://www.pewforum.org/2021/01/27/more-americans-than-people-in-other-advancedeconomies-say-covid-19-has-strengthened-religious-faith/ [Accessed 27 oct. 2020].

Pfefferbaum, B., \& North, C. S. (2020) Mental health and the covid-19 pandemic. New England Journal of Medicine, 383 (6), pp. 510-512. [online] Available at: https://www.nejm.org/doi/full/10.1056/nejmp2008017 [Accessed 16 April 2021].

Pirutinsky, S., Cherniak, A. D., \& Rosmarin, D. H. (2020) COVID19, mental health, and religious coping among American Orthodox Jews, Journal of Religion and Health, 59 (5), pp. 2288- 2301. https://doi.org/10.1007/s10943-020-01070-z [online] Available at: https://link.springer.com/article/10.1007/s10943-020-01070-z [Accessed 21 Jan. 2021].

Powlison, D. (2018) God's Grace in Your Suffering, Wheaton, IL: Crossway.

Rajkumar, R. (2020) COVID-19 and mental health: A review of the existing literature, Asian Journal of Psychiatry 52 [online] Available at; https://www.ncbi.nlm.nih.gov/pmc/articles/PMC7151415/ [Accessed 12 Nov. 2020].

Richards, P. S \& Bergin, A. E. (eds), (2014) Handbook of Psychotherapy and Religious Diversity, $2^{\text {nd }}$ Ed. Washington: American Psychological Association. 
Rogers, J. P., Chesney, E., Oliver, D., Pollak, T. A., McGuire, P., Fusar-Poli, P., Zandi, M. S., Lewis, G., \& David, A. S. (2020) Psychiatric and neuropsychiatric presentations associated with severe coronavirus infections: A systematic review and meta-analysis with comparison to the COVID19 pandemic, The Lancet Psychiatry, 7 (7), pp. 611-627.

Roman N.V., Mthembu T. G, Hoosen M (2020) Spiritual care - 'A deeper immunity' - A response to Covid-19 pandemic, African Journal of Primary Health Care \& Family Medicine 12 (1), pp. 1-3.

Rosmarin, D. H., Pargament, K. I., Krumrei, E. J., \& Flannelly, K. J. (2009) Religious coping among Jews: Development and initial validation of the JCOPE, Journal of Clinical Psychology, 65, pp. 670683.

Rosmarin, D. H., \& Koenig, H. G. (2020) Handbook of Spirituality, Religion, and Mental Health (2nd ed.), London: Academic Press.

Roy, D., Tripathy, S., Kar, S. K., Sharma, N., Verma, S. K., \& Kaushal, V. (2020) Study of knowledge, attitude, anxiety \& perceived mental healthcare need in Indian population during COVID-19 pandemic, Asian Journal of Psychiatry, 52 (102083), pp. 1-7 [online] Available at: https://www.ncbi.nlm.nih.gov/pmc/articles/PMC7139237/pdf/main.pdf [Accessed 29 April 2021].

Rudolfsson, L., \& Tidefors, I. (2014) I have cried to Him a thousand times, but it makes no difference: sexual abuse, faith and images of God, Mental Health, Religion \& Culture, 17 (9), pp. 910 922.

Siedlecki, K., Salthouse, T. A., Oishi, S., \& Jeswani, S. (2014) The relationship between social support and subjective well-being across age, Soc Indic Res. 117 (2), pp. 561-576.

Shader, R. (2020) COVID-19 and depression, Clinical Therapeutics 42 (6), pp. 962-963.

Shirkavand, L., Abbaszadeh, A., Borhani, F., and Momenyan, S. (2018) Correlation between spiritual well-being with satisfaction with life and death anxiety among elderlies suffering from cancer, $J$. Gen. Med. 15, pp. 1-7.

Simonsen, Lone, Chowell, G., Andreasen, V., Gaffey, R., Barry, J., Olson, D and Cécile Viboud (2018) A review of the 1918 herald pandemic wave: Importance for contemporary pandemic response strategies, Annals of Epidomology 28, pp. 81-288.

Singh, D. C., \& Madan, A. (2017) Religious coping in the process of counselling/pschotherpay, Biomed J Sci \& Tech Res, 1 (2), pp. 340-347

Smith, J.A. (2011) Evaluating the contribution of interpretative phenomenological analysis, Health Psychology Review 5 (1), pp. 9-27.

Smith, J.A., Flowers, P. and Larkin, M. (2009) Interpretive Phenomenological Analysis: Theory, Method, and Research. London: Sage.

Smith, J.A., and Osborn, M. (2008) Interpretative phenomenological analysis in Smith, J.A., Qualitative Psychology: A Practical Guide to Research Methods, London: Sage. 
Stauner, N., Exline, J. J., \& Pargament, K. I. (2016) Religious and spiritual struggles as concerns for health and well-being, HORIZONTE-Revista de Estudos de Teologia e Ciências da Religião, 14 (41), pp. 48-75. [online] Available at:

https://www.proquest.com/openview/a038f7796a7c07cc530cbd36e11c73da/1?pqorigsite $=$ gscholar\&cbl=1206337 [Accessed 24 April 2021].

Strawbridge, W. J., Shema, S. J., Cohen, R. D., \& Kaplan, G. A. (2001) Religious attendance increases survival by improving and maintaining good health behaviors, mental health, and social relationships, Annals of Behavioral Medicine, 23 (1), pp. 68-74. https://doi.org/10.1207/S15324796ABM2301 10

Sulkowski, L., \& Ignatowski, G. (2020) Impact of COVID-19 Pandemic on Organization of Religious Behaviour in Different Christian Denominations in Poland, Religion 254, pp. 1-15. [online] Available at: https://www.mdpi.com/2077-1444/11/5/254 [Accessed 15 April 2021].

Thomas, E., \& Savoy, S. (2014) Relationships between traumatic events, religious coping style, and posttraumatic outcomes, Traumatology: An International Journal, 20 (2), p. 84. [online] Available at: https://www.researchgate.net/profile/Elizabeth-Thomas-

18/publication/263918640 Relationships between traumatic events religious coping style and posttraumatic outcomes/links/5783b1e108ae3f355b4a28da/Relationships-between-traumaticevents-religious-coping-style-and-posttraumatic-outcomes.pdf [Accessed 17 May 2021].

Umucu, E., Tansey, T. N., Brooks, J., and Lee, B. (2020) The protective role of character strengths in COVID-19 stress and well-being in individuals with chronic conditions and disabilities: an exploratory study, Rehab. Couns. Bull. 64, pp. 67-74. doi: 10.1177/0034355220967093

Unterrainer, H. F., Lewis, A. J., and Fink, A. (2014) Religious/spiritual wellbeing, personality and mental health: a review of results and conceptual issues, J. Relig. Health 53, pp. 382-392.

VanderWeele, T. J. (2020a) Activities for flourishing: An evidence-based guide, Journal of Positive School Psychology, 4 (1), pp. 79-91.

VanderWeele, T. J., Yu, J., Cozier, Y. C. Wise, L., Argentieri, M. A. Rosenberg, L., Palmer, J. R. \& Shelds, A. E. (2017) Attendance at religious services, prayer, religious coping and religious/spiritual identity as predictors of all-cause mortality in the black women's health study, American Journal of Epidemionlogy, 186 (7), pp. 515-522.

Villani D. Sorgente, A., Lannello, P., \& Antonietti, A. (2019) The role of spirituality and religiosity in subjective well-being in individuals with different religious statues, Frontiers in Psychology, pp. 1-11 [online] Available

at: https://www.frontiersin.org/articles/10.3389/fpsyg.2019.01525/full\#: :text=10.3389\%2Ffpsyg.201 9.01525-

The\%20Role\%20of\%20Spirituality\%20and\%20Religiosity\%20in\%20Subjective\%20Well\%2DBeing,I ndividuals\%20With\%20Different\%20Religious\%20Status\&text=Spirituality\%20and\%20religiosity\% 20have\%20been,not\%20altogether\%20consistent\%20across\%20studies. [Accessed 17 April 2021]. 
Vilog, R. B., Piocos, C. M., \& Bernadas, J. M. A. (2020) Healing "through God's grace": lived religion in Filipina migrant womens's health in Japan, Mental Health, Religion \& Culture, 23, pp. 666-678

Wang, C., Horby, P. W. \& Hayden, F. G.(2020) A novel coronavirus outbreak of global health concern, Lancet, 395 (10223), pp. 470-473.

Wiederhold, B. (2020) Connecting through technology during the coronavirus disease 2019 pandemic: avoiding "Zoom fatigue" , Cyberpsychology, Behavior and Social Networking, 23 (7), pp. 437-438.

Weinberger-Litman, S., Litman, L., Rosen, Z., Rosmarin, D. H. \& Rosenzweig, C. (2020) A look at the first quarantined community in the USA: Response of religious communal organizations and implications for public health during the COVID-19 pandemic, Journal of Religion and Health, 59, pp. 2269-2282.

Yingling, L. \& Froese, P. (2020) Faith and agency: The relationships between sense of control, socioeconomic status, and beliefs about God, Journal for the Scientific Study of Religion 59 (2), pp. 311-26. [online] Available at: https://onlinelibrary.wiley.com/doi/abs/10.1111/jssr.12655?af=R doi:10.1111/jssr.12655. [Accessed 08 Nov. 2020].

Zhang, J., Wo, W. \& Zhao X. (2020) Recommended psychological crisis intervention response to the 2019 novel coronavirus pneumonia outbreak in China: a model of West China Hospital, Precision Clinical Medicine, 3 (1), pp. 3-8.

Zhou, X, Snoswell, C.L. \& Harding, L.E. (2020) The role of telehealth in reducing the mental health burden from COVID-19, Telemed J E Health, 26 (4), pp. 377-379.

\section{About the author}

Sookyung Yang BA (Hons), MA, MBACP.

Sookyung Yang is a counsellor at AHA counselling, in Kingston upon Thames.

She recently completed her MA in Therapeutic Counselling and Psychotherapy at Waverley Abbey College.

Born in South Korea, she spent nearly 30 years in China, Nigeria, and the United Kingdom, fostering her interest in multicultural and diversity issues. She can be contacted at ahacounsellinguk@gmail.com

\section{Copyright}

Copyright 2021 Sookyung Yang 